\title{
TITRIMETRIC APPLICATION OF 2-BROMO- BIS-1, 10-PHENANTHROLINE-COPPER (II) BROMIDE AS A TITRANT IN DETERMINATION OF ASCORBIC ACID IN PURE Form, FruITS AND VEGETABLES
}

\author{
Oluwole Oladeji \\ Department of Pure and Applied Chemistry, Ladoke Akintola University of Technology, \\ P.M.B 4000, Ogbomoso, Nigeria \\ oladeji_oluwole@yahoo.com
}

(Received 13 June 2016 - Accepted 23 October 2016)

\begin{abstract}
Oladeji, O. Titrimetric application of 2-bromo-bis-1, 10-phenanthroline-copper (II) bromide as a titrant in determination of ascorbic acid in pure form, fruits and vegetables. 2016. Lebanese Science Journal, 17(2): 193-199.

Ascorbic acid is very important to man and the consumption has been linked to the prevention of degenerative diseases such as scurvy and serves as an antioxidants. There have been different approaches in the determination of ascorbic acid in fruits and vegetable. In recent times, new methods were introduced by scientists. Therefore, in order to prove the authenticity of these methods, the concentrations obtained were compared with the conventional methods. The results show that orange has maximum ascorbic acid content when compared to cashew and in vegetables Vermonia baldwinii has maximum and Solanium incanum has low ascorbic acid content. The amount of ascorbic acid determined by 2, 6dichlorophenol-indophenol and copper (II) complex (2-bromo-bis-1, 10-phenanthrolinecopper (II) bromide) are comparable. Therefore, 2-bromo-bis-1, 10-phenanthroline-copper (II) bromide can serve as a titrant in titrimetric determination of ascorbic acid in pure form, fruits and vegetables.
\end{abstract}

Keywords: ascorbic acid, antioxidants, titrant, scurvy, 2-bromo-bis-1, 10-phenanthrolinecopper (II) bromide, 2, 6-dichlorophenol-indophenol.

\section{INTRODUCTION}

Ascorbic acid is an essential nutrient found in fruit and vegetables. Vitamin C (Ascorbic acid) is the most important vitamin in fruits and vegetables. Except for human and other primates, most of the phylogenetically higher animals can synthesize vitamin C (L-ascorbate). More than $90 \%$ of the vitamin C in human diets is supplied by fruits and vegetables (including potatoes). Vitamin $\mathrm{C}$ is defined as the generic term for all http://dx.doi.org/10.22453/LSJ-017.2.193199 National Council for Scientific Research - Lebanon 2016@ 1sj.cnrs.edu.lb/vol-17-no-2-2016/ 
compounds exhibiting the biological activity of L-ascorbic acid. Ascorbic acid is the principal biologically active form but L-dehydroascorbic acid, an oxidation product, also exhibits biological activity. Vitamin $\mathrm{C}$ is required for the prevention of scurvy and maintenance of healthy skin, gums and blood vessels. It functions in collagen formation, absorption of inorganic iron, reduction of plasma cholesterol level, inhibition of nitrosoamine formation, enhancement of the immune system, and reaction with singlet oxygen and other free radicals. As an antioxidant, it reportedly reduces the risk of arteriosclerosis, cardiovascular diseases and some forms of cancer (Meister, 1994; Prockop and Kirviriko, 1995).

The chemistry of transition metal complexes has received much attention in recent years on account of their rational design and synthesis in coordination chemistry, also because of their potential applications as functional materials, enzymatic reaction mechanism and in bioinorganic chemistry (Prockop and Kirviriko, 1995). Considerable attention has focused on the synthesis of new copper (II) complexes of salen-type ligands containing bulky groups because of the role in the development of coordination chemistry, and in inorganic biochemistry, catalysis, optical materials (Salid et al, 2008; Vidya et al., 2008).

Coordination compound or metal complex is a structure consisting of a central metal atom, bonded to a surrounding array of molecules or anions, which are in turn known as ligands or complexing agents. Some of the metal complexes are formed virtually irreversibly and many are bounded together by bonds that are quite strong (Miessler and Donald, 1999). Some of the most observed geometrics of coordination compounds are linear for two-coordination, triagonal planar for three-coordination, tetrahedral for four-coordination and so on.

Owing to the wide use of ascorbic acid (AA) in canned fruits, vegetables, animal foods and drugs, to enable the determination of ascorbic acid in different matrices and at different levels many analytical techniques are available such as the titrimetric (Horwitz, 1980), spectrophotometric (US Pharmacopeia), derivative spectrophotometric, colorimetric (Ozgur and Sungur, 1994), kinetic-spectrophotometric, flow-injection spectrophotometric, highperformance liquid chromatographic (HPLC) (Florou et al., 2000), Electroanalytical (Verdmis and Lagier, 2000), capillary zone electrophoresis and molecular electro-kinetic chromatographic methods. The synthesis and the determination of ascorbic acid in pure form, fruits and vegetable using 2, 6- dichlorophenol-indophenol and Bromo-bis-1, 10phenanthroline-copper (II) bromide were undertaken in the present study.

\section{MATERIALS AND METHODS}

\section{Chemicals used}

All chemicals used are analytically graded unless otherwise stated. The water used was double distilled; some of the solvent were distilled.

\section{Collection of samples}

The fresh fruits and vegetables were obtained from a local market in Ogbomoso, Nigeria. They were rinsed with double distilled water to remove impurities. 


\section{Samples preparation}

The fruits samples were peeled squeezed to obtain the extracts. The extract was then filtered using whatman filter paper, the filtrate was collected in a airtight sample bottle. The vegetable samples were cut, and squeezed. The extract was filtered and the filtrate was collected in sample bottles.

\section{Ascorbic acid}

About $0.1 \mathrm{~g}$ of pure ascorbic acid was accurately weighed and dissolved in $100 \mathrm{ml}$ double distilled water in a $100 \mathrm{ml}$ volumetric flask.

\section{2, 6-dichlorophenol-indophenol}

About $0.06 \mathrm{~g}$ of 2,6-dichlorophenol-indophenol was accurately weighed and was transferred into a $500 \mathrm{ml}$ volumetric flask containing $500 \mathrm{ml}$ of double distilled water (carried out according to the method of Salkic and Selimovic, (2015) with slight modifications).

\section{Synthesis of copper (II) complex}

About $2 \mathrm{~g}$ of copper bromide was accurately weighed into a beaker containing $30 \mathrm{ml}$ of double distilled water and agitated for 5 minutes. About $5 \mathrm{ml}$ of ethanol, $0.792 \mathrm{~g}$ of 1,10 phenanthroline was added. The mixture was shaken on a magnetic stirrer for about 8 minutes. This was then filtered and the residues obtained was oven dried for 45 minutes at $4{ }^{\circ} \mathrm{C}$. The filtrate was collected in a clean beaker covered with a perforated aluminium foil for 15 days.

\section{Titrimetric determination of ascorbic acid}

The titrimetric determination of ascorbic acid in fruits and vegetables are carried out according to the method of (Salkic and Selimovic, 2015) with slight modifications, as follows:

\section{2,6-dichlorophenol-indophenol against ascorbic acid}

About $1 \mathrm{ml}$ of acetic acid and ascorbic acid solution were titrated against 2,6dichlorophenol-indophenol. The endpoint was determined and recorded. The procedure was repeated for subsequent analysis.

\section{2,6-dichlorophenol-indophenol against fruits and vegetables}

About $1 \mathrm{ml}$ of the filtrate and acetic acid was titrated against 2,6-dichlorophenolindophenol. The endpoint was determined and recorded. The procedure was repeated for subsequent analysis. 


\section{Copper (II) complex against Ascorbic Acid}

About $1 \mathrm{ml}$ of the ascorbic acid solution was titrated against the copper (II) complex. The endpoint was determined and recorded. The procedure was repeated for subsequent analysis.

\section{Copper (II) complex against fruits and vegetables}

About $1 \mathrm{ml}$ of the filtrate was titrated against the copper (II) complex. The endpoint was determined and recorded. The procedure was repeated for subsequent analysis.

\section{RESULTS AND DISCUSSION}

2,6-dichlorophenol-indophenol is a blue chemical compound used as standard for the determination of ascorbic acid present in any sample. It is a redox dye, when reduced is colourless. During titration of 2,6-dichlorophenol-indophenol against the samples, the blue colour of 2,6-dichlorophenol-indophenol changes to pink. 2-bromo-bis-1, 10-phenanthrolinecopper (II) bromide is not a well-known compound for ascorbic acid determination. The yellow filtrate of the fruit extract changed to green at end point. Table 1 shows the amount of pure ascorbic acid determined by 2,6-dichlorophenol-indophenol and 2-bromo-bis-1, 10phenanthroline-copper (II) bromide have close values. Also, table 2 show that the amount of ascorbic acid determined by 2,6-dichlorophenol-indophenol and 2-bromo-bis-1, 10 phenanthroline-copper (II)bromide from fruits and vegetables show close proximity.

\section{TABLE 1}

The Amount of Pure Ascorbic Acid Determined by 2,6-dichlorophenol-indophenol and 2-bromo-bis-1, 10-phenanthroline-copper (II) Bromide.

\begin{tabular}{|c|c|c|}
\hline Amount taken (ml) & DCI & BPC \\
\hline $\mathbf{1}$ & 3.12 & 2,90 \\
$\mathbf{2}$ & 6.72 & 6.08 \\
$\mathbf{3}$ & 9.00 & 8.46 \\
\hline
\end{tabular}

Legends: DCI = 2, 6-dichlorophenol-indophenol (mg), BPC = Phenanthroline-copper (II) bromide (mg)

Ascorbic acid is the most important vitamin for human nutrition that is supplied by fruits and vegetables. The complex and the standard used (2, 6-dichlorophenol-indophenol, Phenanthroline-copper (II) bromide) react with L-Ascorbic acid in fruits and vegetable samples. This is reversibly oxidised to form L-dehydroascorbic acid $(\mathrm{H})$, which also exhibits biological activity (Davey et al., 2000; Deutsch, 2000). L-Ascorbic acid $\left(\mathrm{H}_{2} \mathrm{~A}\right)$ undergoes the 
oxidation reaction with phenanthroline-copper (II) bromide in an acidic medium to yield dehydro-L-ascorbic acid (A). The oxidation reaction of L-ascorbic acid usually takes place in a two-step reaction. The first step yields a relatively stable ascorbate free radical. In the second one, the L-ascorbic acid free radical donates a second electron, yielding dehydro-L-ascorbic acid. The redox reaction is:

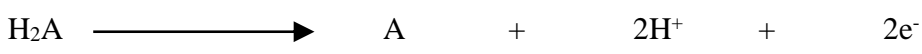

In the attempt of determining the amount of ascorbic acid present in the plant samples, a copper (II) complex was synthesized and the result was compared with the known standard. Results were validated comparing ascorbic acid content obtained by 2, 6dichlorophenolindophenol (AOAC, 1990) with those obtained by the copper (II) complex (2bromo-bis-1, 10-phenanthroline-copper (II) bromide) using titrimetric method (Table 2).

\section{TABLE 2}

The Amount of Ascorbic Acid Determined by 2,6-dichlorophenol-indophenol and 2bromo-bis-1, 10- Phenanthroline-copper (II) Bromide from Fruits and Vegetables (1ml, $2 \mathrm{ml}$ and $3 \mathrm{ml}$ taken)

\begin{tabular}{|c|c|c|c|c|c|c|c|}
\hline \multirow{2}{*}{$\begin{array}{c}\text { Common } \\
\text { name }\end{array}$} & \multirow{2}{*}{$\begin{array}{c}\text { Botanical } \\
\text { name }\end{array}$} & \multicolumn{2}{|c|}{$1 \mathrm{ml}$} & \multicolumn{2}{|c|}{$2 \mathrm{ml}$} & \multicolumn{2}{|l|}{$3 \mathrm{ml}$} \\
\hline & & DCI & BPC & DCI & BPC & DCI & BPC \\
\hline Orange & $\begin{array}{c}\text { Citrus } \\
\text { sinensis }\end{array}$ & 2.50 & 2.90 & 4.400 & 4.280 & 8.467 & 8.389 \\
\hline Pineapple & $\begin{array}{l}\text { Ananas } \\
\text { comosus }\end{array}$ & 2.390 & 6.08 & 4.190 & 4.010 & 8.220 & 8.190 \\
\hline Cashew & $\begin{array}{r}\text { Anacardium } \\
\text { occidentale }\end{array}$ & 1.906 & 8.46 & 3.756 & 3.660 & 7.781 & 7.506 \\
\hline $\begin{array}{c}\text { Fluted } \\
\text { pumpkin }\end{array}$ & $\begin{array}{c}\text { Telfairia } \\
\text { occidentalis }\end{array}$ & 2.185 & 2.125 & 4.185 & 4.125 & 8.160 & 8.000 \\
\hline Bitter leaf & $\begin{array}{l}\text { Vermonia } \\
\text { baldwinii }\end{array}$ & 2.100 & 2.050 & 4.100 & 4.050 & 8.090 & 7.904 \\
\hline $\begin{array}{l}\text { African } \\
\text { spinach }\end{array}$ & $\begin{array}{c}\text { Amaranthus } \\
\text { hybidus }\end{array}$ & 2.157 & 2.090 & 3.960 & 3.090 & 7.220 & 7.070 \\
\hline $\begin{array}{c}\text { Feather } \\
\text { cockscomb }\end{array}$ & $\begin{array}{l}\text { Celeosia } \\
\text { argentea }\end{array}$ & 2.050 & 2.010 & 4.050 & 3.910 & 7.290 & 7.100 \\
\hline Spinach & $\begin{array}{l}\text { Solanium } \\
\text { incanum }\end{array}$ & 2.305 & 2.295 & 4.205 & 4.185 & 8.200 & 8.050 \\
\hline
\end{tabular}

Legends: DCI = 2, 6-dichlorophenol-indophenol (mg), BPC = Phenanthroline-copper (II) bromide $(\mathrm{mg})$ 
The result of estimation of ascorbic acid in some local fruits and vegetables are shown in Table 2. The results obtained are comparable with other studies carried out on the estimation of ascorbic acid from some local fruits and vegetables. The results showed that in the fruits samples, orange has maximum ascorbic acid content and cashew has lowest ascorbic acid content and in vegetables Vermonia baldwinii have the highest and Solanium incanum has lowest ascorbic acid content. The results obtained from table 1 to 2 showed that the amount of ascorbic acid determined by 2, 6-dichlorophenolindophenol and copper (II) complex (2-bromobis-1, 10-phenanthroline-copper (II) bromide) are comparable. This show that copper (II) complex (2-bromo-bis-1, 10-phenanthroline-copper (II) bromide) can also serve as a standard for the determination of ascorbic acid in fruits and vegetables.

Fruits and vegetables are always available in local markets and they are also not expensive, the considerable amount of ascorbic acid presents in these fruits and vegetables showed that when they are consumed in relative large amount, they will certainly contribute to the daily human dietary intake of the vitamin. It is to be noted that the requirement of ascorbic acid increases during pregnancy, lactation, adolescence, hyperthyroidism, infection and after surgery (Achine, 1983) Maintenance of daily dietary intake of ascorbic acid led to the prevention of scurvy which is the deficiency disease state of vitamin C. This disease has been shown to be high in children and the elderly (Davidson $e t$ al., 1972).

\section{CONCLUSION}

As a result of the high precision, the proposed method is sensitive and suitable for the determination of ascorbic acid. The method affords enough sensitivity and selectivity in Lascorbic acid determination in tropical fruits [orange, cashew and pineapple]. The method showed that the Citrus sinensis and Cucurbifa maxima contained the highest amount of ascorbic acid while Anacardium occidentale and Solanium incanum contained the lowest in fruits and vegetable samples respectively. Therefore, 2-bromo-bis-1, 10-phenanthroline-copper (II) bromide can serve as a titrant in titrimetric determination of ascorbic acids in pure form, fruits and vegetables.

\section{ACKNOWLEDGEMENTS}

The author appreciates the efforts of the Department of Pure and Applied Chemistry, LAUTECH, Ogbomoso for their support and assistance with the information provided.

\section{REFERENCES}

Achinewhu S. C. 1983. Ascorbic acid content of some Nigeria local fruits and vegetables. Qualities Plantarium Plant Foods for Human Nutrition, 33 (4): 261-266.

AOAC. 1990. Official methods of analysis of the Association of Official Analytical Chemists, 15th ed., Association of Official Analytical Chemists, Arlington VA 1990. pp. 10581059

Davey, M. W., and Van Montagu, M., Inzé, D., Sanmartin, M., Kanellis, A., Smirnoff, N., Benzie, I. J. Strain, J. J., Favell, D., \& Fletcher, J. 2000. Plant L-ascorbic acid: chemistry, function, metabolism, bioavailability and effects of processing. Journal of the Science of Food and Agriculture, 80: 825-860. 
Davidson, S., Passmore, R. and Brocks, J. A. 1972. Human Nutrition and Dieterics. Churchill, Livingstone, London 8th Edition.

Deutsch, J. C. 2000. Dehydroascorbic acid. Journal of Chromatographic Analysis, 881: 299307.

Florou, A.B., Prodromidis, M.I., Karayannis, M.I., and Tzouwara-Karayanni, S.M. 2000. Flow electrochemical determination of ascorbic acid in real samples using a glassy carbon electrode modified with a cellulose acetate film bearing 2, 6dichlorophenolindophenol. Anal. Chim. Acta., 409: 113-121.

Horwitz, W. 1980. Editor: Official Methods of Analysis of the Association of Official Analytical Chemists, 11th ed. Association of Official Analytical Chemists. 777 pp. Washington DC.

Meister Allon. 1994. Gluthatthione-Ascorbic acid antioxidant system in mammals. The Journal of Biological Chemistry, 269 (13): 93-410.

Miesslar, G. L., and Donald, A. T. 1999. Ascorbic acid. Inorganic Chemistry. p. 315-316.

Ozgur, M.U. and Sungur, A. 1994. Spectrophotometric method for the determination of prazosin hydrochloride in tablets. Turk. J. of Chemistry, 18: 68-72.

Prockop, D.J and Kiviriko, K.I 1995. Collagens: Molecular biology diseases, and potentials for therapy. Annu Rev Biochem., 64: 403-34.

Salid H., Guzar, J.I.N. and Qin-han. 2008. Synthesis, characterization and spectra studies of new Cobalt (II) and copper (II) complexes of Isonitinoylhydrazine. Journal of Applied Sciences, 8: 2480-2485.

The United States Pharmacopeia XX and the National Formulary XV-United States Pharmacopeial Convention, 1980, Inc., 55 pp., MD.

Verdini, R. A. and Lagier, C.M. 2000. Voltammetric Iodometric Titration of Ascorbic Acid with Dead-stop End-Point Detection in Fresh Vegetables and Fruit Samples. J. Agric. Food. Chem., 48(7): 2812-2817.

Vidya Vati Reddy, Nirdosh Patil, Tukaram Reddy A and Angadi, S.D. 2008. Synthesis, characterization and biological activities of $\mathrm{Cu}$ (II), $\mathrm{Co}$ (II), $\mathrm{Ni}$ (II) and $\mathrm{Fe}$ (II) complexes with Schiff bases derived from 3-(4-chlorophenoxymethyl)-4-amino-5mercato-1,2,4-triazole. E-Journal of Chemistry, 5 (3): 529-538. 